\title{
HSP90AA1 Gene
}

National Cancer Institute

\section{Source}

National Cancer Institute. HSP90AA1 Gene. NCI Thesaurus. Code C97586.

This gene is involved in both protein folding and nitric oxide metabolism. 